\title{
Curriculum Management To Optimize Islamic Studies Course At Public Universities
}

\author{
Mukniah \\ Pos-el: mukniah@gmail.com \\ Institut Agama Islam Negeri Jember
}

\begin{abstract}
Public universities (hence abbreviated: PTU) and Religious universities (abbreviated: PTA) are different from each other. PTA focus on studies of specific religion, while PTU deal with general knowledge not even related to religious dogma. Nevertheless, Indonesian education system needs to take account of curriculum management-as the proces of planning, organizing, implementing and evaluating curriculum-especially for the subject of Islamic studies (abbreviated: PAI, stands for Pendidikan Agama Islam) at Public Universities (PTU). However, the subject of Curriculum Management and Islamic studies (PAI) are frequently considered to be additional subjects, yet in fact they could play a pivotal role as subjects for character building (MPK). Therefore, these particular subjects should be taken into account by the decision makers. The reserach was aimed at analysing and identifying the appropriate model of curriculum management and education to optimise Islamic studies (PAI) course at the public universities (PTU).
\end{abstract}

Keywords: Management, Curriculum, Islamic Education, Public Universities

\section{Introduction}

Education is a long process for improving human resources. Therefore, through education all potentials of human being are expected to maximally develop in which it is in line with the purpose of national development and philosophy to build a better character of the nation.

Consequently, educational institution plays a pivotal role to achieve the objectives of national education. Therefore, to achieve an efficient as well as effective result of national education objectives, they are expected to take into account some managerial concerns such as curriculum management and learning which deal with planning, organizing, implementing, monitoring, and evaluating as part of components and functions of management. ${ }^{1}$

Curriculum is the essential component which should be incorpoarated in education. Curriculum is the comprehensive guideline leading which way the education is implemented. Teaching and learning are the major process of education. In addition, learning is the practical implementation of curriculum. In other words, curriculum will not likely be efficiently transfered to students without learning process. Without a clear guideline of curriculum,

1 Winoto, S. Manajemen berbasis Sekolah, ( School Based Management) (Jember : Pena Salsabila, 2011), p.6 
learning will then unlikely be processed effectively as well as efficiently. ${ }^{2}$

Curriculum management and learning are such a comprehensive knowledge, art, and even skills. It needs feedbacks, knowledge, practical techniques and even communication. Curriculum management and learning are the process oforganizing, managing, managing curriculum and learning process, either organizing curriculum,or lecturers' activities as the curriculum practitioners or evaluation system used to effectively as well as efficiently to achieve the learning goals.

Based on such definition curriculum management and learning is the process of management to plan, to organize, to apply and to evaluate the learning and teaching process as the interaction between educator and students to achieve the learning objectives.

As the mandate of National Education System Regulation No. 20, 2003 article 37 verse 2 , that the curriculum of high education is obliged to accomodate religious study, the education of citizenship, and language. This means that Islamic studies (PAI) becomes the institutional obligation. Religious education is considered to be important as it plays a pivotal role in building up the characters of students, individuals, peoples and even Indonesian nation.

As a matter of fact, however, according to Kasman,the subject of Islamic studies in the public universities is relatively eliminated as most students pay insufficient attention, show

2 Gunawan, H.Kurikulum dan Pembelajaran Pendididikan Agama Islam, (Curriculum and Teaching of Islamic Education) (Bandung:Alfabeta, 2013), p.iii inconsiderable courage and interest to the subject of Islamic studies. It is apparently considered to be an extra subject. Even worse, the university decision makers / board of management and organizers do not take the subject of Islamic studies into thoughtful consideration. ${ }^{3}$

Zainal Anshari also stated through his research that the curriculum of Islamic studies in public universities are such an ideal course but not applied with the same quality in reality. In fact, PAI gets less portion of around 2-3 SKS the least of all subjects. As a matter of fact, the implementation of PAIdoes not get substantial potential support from the decision maker / board of management in the university, so that PAI seemingly becomes the subject of second class with no sufficient attention from the students though most of them are moslems.

In addition, proper Religious Study will likely result noble individuals measured from two dimensions of relationship namely with God The Almighty and with His creations, with the meaning of creation is not mainly about mankind but also the environment.

The subject of Islamic studies aims to form a complete islamic character, to develop physical as well as mental potentials of mankind, develop harmonious relationship of each individuals with Allah the almighty, human beings and universe.Islamic studies concern the education of balance.

3 Kasman,"Faktor-Faktor yang Mempengaruhi Motivasi Mahasiswa dalam Mengikuti Perkuliahan Pendidikan Agama Islam pada Perguruan Tinggi Umum di Kabupaten Jember Tahun 2005," (The factors influenced students' motivation to attend courses at the public universities in the district of Jember in 2005) Fenomena, Jurnal Penelitian STAIN Jember, 2 Vol.5, (Juli, 2006), p.24 
The principle of balance in the Islamic studies becomes the specific feature, for instance the physical and mental balance, individuals-community, earth and the hereafter, and the balance of intelectual-emotional. This is in line with the objectives of national education formulated in the regulation number 20, 2003 about National Education System (UU Sisdiknas) Chapter II as what follows:

National education functions to develop skills and build the people's character and noble civilization to liven up the nation,also to develop the students' potentials to be religious individuals with good behaviour and respect God the Almighty, healthy, knowledgeable, reliable, creative, independent, and become democratic citizens and responsible. ${ }^{4}$

Yet, in fact, the objective does not seem to have been implemented properly especially in the level of education including the public universities (PTU). In additon, most people also do not pay special attention to the importance of Islamic studies for young generations.

Islamic studies in public univeristies regulated in regulation of the Republic of Indonesia No. 12, 2012 about higher education at chapter and verse (2) The curriculum of higher education is developped by each university referring to the National Standard of Higher Education for each study program which cover the development of intellectual intelligence, good behavior and skills, the verse (3) suggested that the curriculum of higher education should cover the subjects of a) Religion, b) Pancasila, c)

4 Undang-Undang RI (The Republic of Indonesia's Law) No: 20 Year 2003 about Indonesian Education System (SISDIKNAS), p. 68.
Citizenship, and d) Bahasa Indonesia. ${ }^{5}$ In addition, according to government regulation Number 19, 2005 on The National Standard Of Education chapter 9 stated that: (1) basic framework and curriculum structure of higher education is developped by university in relation to each study program; (2) of higher education is obliged to cover religious study, the education of citizenship, Indonesian language, and English language; (3) Aside of what is stated in verse (2), the curriculum of higher education of under graduate and diploma programare obliged to cover subjects comprising study of Personality, Culture, and Statistics, and / or Mathematics; and (4) curriculum of unit of educational level and the in-depth ofthe curriculum content of higher education is organized by each university. ${ }^{6}$ Beside PP number 19, 2005 on National Standard of Education, religious study at the public universities is organized through letter of confirmation of Directorate General of Islamic studies N0.DJ.I/78/2011 on National Standard of Islamic studies at The public universities.

Thus, lecturers of Islamic studies (PAI) public universities (PTU) obtain authority to develop materials in need, government, institutions or government. Subject Islamic studies (PAI) public universities (PTU) is part of subjects of personality development (MPK). MPKPAI at PTU is provided to make students religious individuals and respect God the Almighty and posses good behavior as the implementation religious values.

5 Higher Education Law No.12 Year 2012, Jakarta, (Sinar Grafika), p.30.

6 Standar Nasional Pendidikan (National Education Standard) Government Rule (PP).No. 19 Year 2005.Chapter 9.Which was changed into Government Rule(PP)No.32 Year 2013 (Bandung : Fokusmedia), p.10 
Islamic studies (PAI) should be continuously empowered to eventually realize expected national education, and able to solve problems. The empowerment can be in the form of ideas, thoughts, institutions, curriculum, management, governmental policies,et cetra. $^{7}$

Public universities which treat Islamic studies as one of general subjects (MKU) to be taken by all moslem students, should expectedly be able to manage curriculum and the learning of Islamic studies well that the purpose of the learning of Islamic studies will thus become the sub-system of national education objective.

Curriculum isthe guidance in the educational activities carried out at institutions to achieve certain educational objective. Thus, curriculum should be well-managed that all educational activities including learning can be more productive. The management of curriculum is related to the management of learning experience which needs specific strategy for more productive learning. The strategies begins with planning, organizing, executing, and evaluating supported by sufficient resources.

Lecturers have strategic positions as they can directly manage the teaching and learning process especially for students of under-graduate study (S1). The quality of proess and learning results can especially be determined through class meetings. The lecturers' empirical knowledge and skills will eventually help students develop their scientific attitude. ${ }^{8}$

7 Daulay, H.P. Pemberdayaan Pendidikan Islam di Indonesia, (Islamic Education Reinforcement in Indonesia), p. 2.

8 Uwes, S. Manajemen Pengembangan Mutu Dosen, (Management of Quality Improvement of
Therefore, it is such a challenge for those in charge in the university level to improve the lecturers' professional quality that they can manage curriculum and learning in need. The development and the improvement of lecturers' professional quality will likely fulfill the community's expectation to result graduate with good behaviorand eventually can get job, by being recruited at established institutions or even running their own businesses to be eventually developed toward a more positive prospect in the future. ${ }^{9}$

In general, education deals with challenges of low learning process. This is due to the focus merely on cognitive skills such as remembering information. This way, it burdens the students' thought to forcefully save some information with a lack of comprehension related to that of real life. ${ }^{10}$

Public universities which have authority of managing some courses especially those related to subjects of personality development such as islamic studies tend to fulfill Term Course Credit (SKS) to be taken by all moslem students that after the PAI course, no further course run, and the students consider the final examination (UAS) is the clue that the course has completed.

The problem of curriculum management and the learning of PAI often encountered in higher education

Lecturers), (Jakarta: Logos Wacana Ilmu,1999), p. 14.

9 Surachmi, S.“Pengembangan Profesi Pendidik dan Tenaga Kependidikan di Sekolah" (Developing professional educators and education manpower at schools) , Jurnal Ilmu Pengetahuan Sosial, 4Volume X, (Oktober, 2008), hlm.65.

10 Sanjaya, W.Strategi Pembelajaran Berorientasi Standar Proses Pendidikan (The Learning Strategy Based on Standard of Process in Education), (Jakarta: Kencana,2006), p. xi. 
includes:First, PAI courses are not considered as core courses or even the supplementary ones. This way, the management of PAI does not gain a considerable attention. However, lecturers of PAI have a special privilege to design the curriculum and learning.

Second, the objectives of Islamic studies and what is reflected in reality collide though the implementation of curriculum management and learning such as planning, organizing curriculum and learning, and monitoring and evaluation systems take place as expected.

Third, PAI lecturers are insufficiently provided. Lack of lecturers will likely burden them with teaching tasks and excessive workloadsso that the guidance of students with post-class assignments can hardly be conducted. Nevertheless, several PAI lecturers provide coaching via online to reach the target of effective and efficient learning.

Fourth, the ratio of lecturers to students has not met the standards in which mostly 50 students involve in each class of PAI while a maximum of 40 should join in the class.

Fifth, in general, PAI lecturers do not meet academic qualifications of at least a master degree from accredited domestic or foreign universities. ${ }^{11}$

The problems of curriculum management and learning require comprehensive solution. Thus, good model of curriculum development and learning through effective management should be taken into serious consideration

\section{Curriculum Management and Learning}

As curriculum management consists of two words; management and curriculum, Gurlick suggested that management is a field of knowledge that systematically tries to understand why and how people work together. ${ }^{12}$

Whereas, Terry defines "management is a distinct process consisting of planning, organizing, actuating and controlling, performed to determine and accomplished stated objectives by the use of human beings and other resources". Thus, management is a process which consists of planning, organizing, implementing and monitoring carried out to determine and achieve goals using human resources and other reliable sources.

In addition, Parker suggested that management is the art of carrying out work through people. Whereas, management in a broader sense includes planning, organizing, directing, and controlling organizational resources to achieve goals effectively and efficiently. ${ }^{13}$ Hence, Based on several management understandings above, management is merely knowledge and art which involves systematic aspects, a process of cooperation and effort through people, regulation, direction, coordination, evaluation to achieve goals and in line with funding, tools, methods, time and place.

The essence of management is the process of managing an organization. Furthermore, management is the process of achieving organizational goals in an effective and efficient way through

12 Fattah, N.Landasan Manajemen Pendidikan, (The Principles of Education Management), (Bandung: Remaja Rosdakarya,1999), p. 13.

13 Usman, H. Manajemen; Teori, Praktik dan Riset Pendidikan (Management: Theory, Practice, and Educational Research), (Jakarta: Bumi Aksara,2010), p. 5.

11 Ibid., 51 
planning, organizing, leadership, and controlling organizational resources. ${ }^{14}$

Curriculum is a written plan containing ideas formulated by curriculum specialists. It then becomes documents as part of curriculum and teaching system; a guideline for lecturers in managing the classroom learning process. ${ }^{15}$

Thus, curriculum management and learning is the management of planning process, organizing, implementing and evaluating the teaching-learning process.

\section{Curriculum Planning and PAI Learning}

Curriculum is an essential effort to produce better outcomes or to ensure students to achieve and develop competence. Competence is a good combination of knowledge and skills mastery and attitudes.

Planning is a systematic thought to achieve goals. Planning functions to determine the goals or action frameworks. Related to this, Fatah states that planning is the process of determining the goals or objectives to achieve, determining the stages and resources efficiently and effectively. ${ }^{16}$

Based on the organizational point of view, curriculum planning and learning play a pivotal role in determining the objectives and intentions of curriculum development, environmental issue, and determining approaches in which curriculum

14 Daft Richard L, Manajemen (Management) Translate: Emil Salim, et.al, (Jakarta: Erlangga, 2002), p. 8.

15 Sanjaya, W.Kurikulum dan Pembelajaran: Teori dan Praktik PengembanganKurikulum Tingkat Satuan Pendidikan (KTSP) (The Curriculum and Learning: Theory and Practice to Develop the Indonesian KTSP Curriculum), (Jakarta: Prenandamedia Group, 2015), p.16.

16 Fatah, N. Landasan Manajemen Pendidikan, (The Principle of Education Management), p. 98. development goals and objectives need to be achieved. This way, mangerial leaders including heads of the universities have ample opportunity to develop their universities or institutions.

The curriculum is a process resulted from the analysis process from various inputs. First, the vision and mission of institution are the direction of educational institutions implemented in a more detail form of planning. Curriculum is the most important planning in educational institutions. ${ }^{17}$

Second, factor of idealism of the educational institution leaders can influence various planning in institution, curriculum included.

Third, it concerns the needs of stakeholders of the educational institutions. As expected, universities should be able to provide balance between graduates' competencies in mastering science and technology and increasing faith, empathy and noble character. College curriculum should be able to design both aspects of science and technology and aspects of faith, piety and noble character in a balanced way. ${ }^{18}$

Fourth, resources availability will more likely affect university curriculums. As human is the most important resource, the availability of competent lecturers will certainly influence the curriculum and environmental conditions.

Fifth, it concerns the characteristics of student which relate to age, economic

17 Muhaimin, et.al, Pengembangan Model Kurikulum Tingkat Satuan Pendidikan (KTSP)pada Sekolah \& Madrasah.(The model of development of curriculum of KTSP in public and Islamic schools), p. 25.

18 Muhaimin, et.al, Pengembangan Model Kurikulum Tingkat Satuan Pendidikan (KTSP)pada Sekolah \& Madrasah (The model of development of curriculum of KTSP in public and Islamic schools), p. 26. 
conditions, education, family and social conditions. ${ }^{19}$

Hamalik suggested that the curriculum was designed to realize the goals of national education through students' developmental stages and their suitability with the environment, national development needs, the development of science and technology and art in accordance with type and level of each educational unit. ${ }^{20}$

Curriculum development and implementation requires proper condition and atmosphere of scientific environment such as college (campus). Thus, campus environment should be based on academic freedom autonomy. Various inputs are analyzed by the university leaders who normally produce the curriculum. Yet, in fact, curriculum will be implemented through graduates' competencies.

Hence, curriculum should be documented. Thus, certain inps as well as the composition of the development team in line with national standard are needed. ${ }^{21}$

Therefore, in implementing ideas into curriculum some points such as national standards and guidelines should be taken into consideration so that the curriculum meets national standard as it involves all components in the university. In addition, curriculum must also have technical plans such as syllabi and lesson

19 Ibid., 27.

20 Hamalik, O.Pengembangan Kurikulum dan Pembelajaran; Dasar dan StrategiPelaksanaannyadi Perguruan Tinggi (Curriculum Development dan Learning: Principle and the Strategy of Implementation in Universities), (Bandung: Trigenda Karya, 1994), pp. 41-42.

21 Muhaimin, et.al, Pengembangan Model Kurikulum Tingkat Satuan Pendidikan (KTSP)pada Sekolah \& Madrasah (The model of development of curriculum of KTSP in public and Islamic schools), p. 28. plans (RPP) in which all lecturers are involved. ${ }^{22}$

The series of well-planned as well as well-written curriculum will likely achieve expected graduate's competencies. Curriculum will surely be unimplementable if it is never executed.

Public Universities (PTU) when implementing Islamic Study courses are different from that of Islamic Religious Universities (PTKI) such as IAIN, STAIN and even from some other religious universities such as State Islamic University of Malang, Jember State Islamic Institute, Bandung State Islamic University, etc. Thus, in relation to planning, implementing and evaluation stages above-mentioned institutions have different mechanisms.Based on such differences, the improvement and implementation quality of religious education at PTU need further actions conducted by both government and the higher education institutions.

As mandated by the National Education System Law No. 20, 2003 article 37 verse 2, Islamic Religious Education becomes an institutional obligation. Religious education is considered to important it plays a pivotal role for individuals, communities and nations. Thus, proper religious education will likely lead into a complete human with two-dimensional angle of relationship; with God and with human beings.

For instance, the course vision and mission on development belonging to Islamic religious education of State University of Jember suggested that to make Islamic teachings a source of values and guidelines that lead students to develop Islamic personalities who are

22 Ibid 
faithful and devoted, knowledgeable and noble and to make Islamic teachings as a foundation of thinking and behaving for professional development. ${ }^{23}$

The Curriculum planning for PAI learning begins with needs analysis by lecturer in accordance with number of students and class, lecture plot or courses distribution. In addition to considering the ratio of lecturers and students number, curriculum planning and learning also consider student needs, learner analysis; their needs and levels of ability. ${ }^{24}$

Furthermore, lecturers need to plan learning which deals with syllabus, lesson plan (RPP) and semester program or lecture program Unit (SAP).

Syllabus development technique especially for Islamic Education (PAI) courses at PTU is generally carried out through meetings of PAI subject lecturers highlighting orientation, direction, division, and action proceeding. Lecturers of PAI courses also have ample time to develop syllabus for better understanding.

Furthermore, PAI lecturers also have authority to analyze the syllabus. This way, they can add, organize and adapt the situation and conditions in the classrooms, also improvise and develop materials by which suit the student needs.

\section{Curriculum Organization and PAI Learning}

Organizing is a comprehensive process of selecting people, allocating

23 Document, Modul Acuan Proses Pembelajaran Mata kuliah Pengembangan Kepribadian(PAI) (Module Reference of Learning Process for Personality Development Course)UPT.BSMKU, Jember University

24 Siddiq, M. Interview: 5 November 2014, Office: UPT.BSMKU, Jember University facilities and infrastructure to support the each member concerns in the organization.Gibson in Syaiful, stated that organizing is part of managerial activities carried out to realize planned activities into a task structure, authority and determined who will carry out certain tasks to achieve the organization goals. ${ }^{25}$

Fatah classifies stages in organizing process into five stages as follows: (1) Determine which tasks must be executed to achieve organizational goals. (2) Divide all workloads into doable activities that to be carried out by individuals or groups based on certain qualifications. (3). Works of members are combined in a rational, efficient way. (4). Create a working mechanism to coordinate work in harmony. (5). Monitor and take adjustment steps to maintain and improve effectiveness. ${ }^{26}$

Based on the facts above, effectiveness in organization can determine clearness of task divisions, rights, responsibilities, working relationships and also determine which individual to carry out the duties. Thus, organizing is the process of determining the essential relationships among people, tasks, and activities by integrating and coordinating all organizational sources to achieve goals effectively and efficiently.

Whereas, according to Sutopo organizing activities should comprise several actions such as (1) working identification, (2) works tasks division, (3) task classification, (4) position determinations, (5) tasks or work determination, and (6) Personnel,

25 Syaiful, Administrasi Pendidikan Kontemporer (Bandung : Alfabeta, 2000), pp. 49-50.

26 Fattah, N.Landasan Manajemen Pendidikan..hlm.72. 
facilitators and other sources management. ${ }^{27}$

Aside of that, the organization of curriculum development at PTU is an effort to establish cooperation among individuals in a group consisting of assigning duties, authorities, responsibilities, and their respective relationships in planning, directing and controlling curriculum development.There are four tasks dealing with curriculum development organization namely; (1) Task and responsibility division, (2) Authority delegation, (3) number of available positions, and (4) work fields grouping.

PAI curriculum development is specifically needed. In the implementation, lecturers need creativity to empower the learning and eventually reach the targets. The organization of the PAI curriculum is appointed by the University and relevant to the need of PAI lecturers. ${ }^{28}$

When explored further, organizing the curriculum does not merely concern the management of learning resources. In relation to this, Syafrudin suggested that organizing curriculum in learning includes: (a) Selecting proper strategies, (b) Selecting appropriate learning aids, (c) Setting the size of the class (dealing with the number of students), (d) selecting proper strategy to communicate complex rules, procedures and teaching. ${ }^{29}$

In general, the curriculum and PAI learning model at PTU is divided into two; first, the organization of the PAI curriculum and learning refer to Top-

27 Ibid. p.72

28 Syafruddin and Nasution, I.Manajemen Pembelajaran (Learning

Management),(QuantumTeaching: Jakarta, 2005), p. 10.

29 Ibid. P.10
Down approach directly organized by the implementation of unit then forwarded to each PAI lecturer.

Second, Bottom-up approach also works. It means that PAI curriculum is based on the organization of each lecturer in PAI courses.It will more likely develop due to the lecturers' autonomy and authority to develop PAI learning. Thus, lecturers are required to have a great creativity.

\section{Curriculum Implementation and Learn- ing}

The implementation of curriculum through academic activities in universities requires adequate conditions. The implementation of curriculum and learning of Islamic religious education is an embodiment of curriculum planning designed in previous stage (planning), then implemented and managed according to the classroom situation, student characteristics, intellectual, emotional, spiritual and physical development.

Lecturer competence of material and learning strategies, skills in using and utilizing learning resources are also important to enable curriculum to obtain adequate practice. ${ }^{30}$

Success or failure of the planned Islamic education curriculum and learning depends on the teachinglearning process. Planned teaching and learning process will determine successful curriculum implementation.

In university contexts, lecturers and students are elements ensuring the learning objectives achievement. The success of students closely relate to

30 Muhaimin, et.al, Pengembangan Model Kurikulum Tingkat Satuan Pendidikan (KTSP)pada Sekolah \& Madrasah (The model of development of curriculum of KTSP in public and Islamic schools), p. 29. 
personal processes in internalizing knowledge, attitudes, values, traits and skills while lecturers' success is determined not only by personal quality but also by reasonable number of lecturers towards number of students. ${ }^{31}$

Moreover, lecturers must master various learning abilities, learning strategies included. Learning strategies are directed at learning, also learning trends especially in the information age which prioritize result-based, individualbased and resource-based needs (based on learning resources).

Learning strategy expectedly leads to: (1) learning mastery, (2) Continuous learning progress; (3) Personal learning plans according to students' needs; (4) Performance based assessment (assessment is carried out based on performance); (5) Performance based learning; (6) Cooperative learning or learning by working with certain groups; (7) Use of Advanced technologies as learning tools; (8) Teacher as coach or facilitator (the role of lecturers as trainers or facilitators; (9) Thinking skills and making meaning (developing thinking and meaningful skills); and (10) Interpersonal skills (developing skills and interpersonal relationships. ${ }^{32}$

Competency Based Curriculum (KBK) developed in Higher Education categorizes courses into 5 groups. 1). Skills and Skills (MKK) group, 2). Work

31 Uwes, S.Manajemen Pengembangan Mutu Dosen, (Management of Developing Quality of Lecturers) Disertasi Doktor (Doctoral Dissertation), (IKIP Bandung, 1999), p.1.

32 Muhaimin, Pengembangan Pendidikan Ulul Albab di UIN Malang (Developing UlulAlbab Education in State Islamic University of Malang) in Zainuddin, M. et.al,Memadu Sains dan Agama Menuju Universitas Islam Masa Depan, (Collaborating Science and Religion toward Future Islamic University), (Malang: UIN Malang Press, 2004), pp. xxxi-xxxii.
Skills Course (MKB) group, 3). Work Behavior (MPB) course group, 4). Personality Development Course (MPK) group, 5). Community Living course (MPB) group.

The first to third group courses are managed by Faculties and Departments / Study Programs. This group has a number of Facultural courses in which students from various Departments / Study Programs in the Faculty should take particular courses as faculty competencies.

PAI course can be taken in any faculty / department within the University. It has been implemented and collaborated with technology and information (IT) units in the University of Jember to handle the programming process. Students can register general courses through the academic administration system (Siakad). However, especially for general courses, individual "overing" with a class model of a maximum of 70 to 80 people is required.

Joint lectures in groups of general subjects such as PAI can also be carried out. This way, University provides lecture rooms and their facilities according to needs, to be managed by the implementing unit to serve lectures for students from various faculties / departments. The number of classrooms are used to serve all students participating in general subject courses per semester from various majors / study programs.

\section{Curriculum Monitor and Evaluation and Learning}

Monitoring and evaluatng curriculum is a systematic effort to collect information about curriculum to be used as a consideration regarding the process 
of implementation, value and meaning of the curriculum in a particular context. ${ }^{33}$

Monitoring and evaluating are two integrated activities to control a program. However, monitoring and evaluating have a different focus. These systems highlight how program implementers can obtain data / information accurately to improve program implementation.

Monitoring and evaluating will be less useful without immediate actions as it is important for decision making for the improvement of program implementation. Nevertheless, inaccurate monitoring and evaluating can lead to poor decision making. Therefore, monitoring and evaluating system should be designed in such a way for accurate and timely data / information.

Schereens endured that the system increases the effectiveness of educational programs such as (1) external stimulus, (2) special programs, (3) special characteristics with campus context, (4) university-stakeholder partnerships, (5) curriculum planning and development, (6) professional leadership, (7) lecturer experience, (8) learning environment, (9) study time, and (10) progress monitoring. ${ }^{34}$

Stages in the design of monitoring and evaluation starts from making an introduction highlightingreasons why monitoring and evaluation must be carried out. Furthermore, determining legal basis becomes a reference in accordance with monitored and evaluated program with each meaning.

33 Arikunto,

S.PengelolaanKelasdanSiswa:SebuahPendekatanE valuatif (Classroom Management: an Evaluative Approach), (Jakarta:CV. Rajawali, 1986), pp. 27-28

34 Schereens, J. Menjadikan Sekolah Efektif ( Making School Effective), (Jakarta : Logos, 2003), p.157.
The next stage is to make basic principles of monitoring and evaluating tailored to the needs of the program, evaluated and continued by program determination. After the completion, formulating objectives needs to be taken. Furthermore, the benefits of monitoring and evaluation, the work plan of monitoring and evaluation, the place of monitoring and evaluation, the implementation of monitoring and evaluation, the implementation of monitoring and evaluation systems, the method of monitoring and evaluation, and reporting and dissemination of monitoring and evaluation need to be taken and adjusted to the program determined to implement the monitoring and evaluation system. ${ }^{35}$

Monitoring is carried out through regular data collection based on certain indicators to find out whether the ongoing activities are in accordance with plans and procedures. Monitoring indicators include the essence of activities and targets set at the beginning of program planning.

When monitoring is conducted properly, it will be useful to maintain the process of activity implementation process (according to program guidelines and planning), and providing information to program managers as well as giving inputs in conducting evaluationswhen obstacles and irregularities occurunder any circumstances.

Evaluation focused more on the program results. Thus, periodic evaluation as a systematic process of collecting, analyzing, and interpreting

35 Ministry of National Education RI, 2013, Module of Training and Development of Monitoring and Evaluation System of Education, p. 24. 
data is to determine the success rate of a program, as well as identify which program components work well. This can be used forimproving correction material or decision making for the direction of future program policies.

Evaluation can be conducted in a formative way (carried out while the program is still running) with the aim of improving the program implementation strategy, or summatively carried out after the program completion as learning material for the implementation of similar programs in the future. Evaluation has a different meaning than assessment, measurement or test. Stufflebeam and Shinkfield state that:

Evaluation is the process of delineating, obtaining, and providingdescriptive and judgmental information about the worth and merit of some object's goals, design, implementation, and impact in order toguide dicision making, serve needs for accuntability, and promote understanding of the involved phenomena. 36

Scriven, as quoted by Hasan, formulates the function of curriculum evaluation in formative and summative terms. The formative function of a curriculum can only be carried out when the evaluation merely deals with the process and not the results. On the contrary, summative function cannot be applied when the curriculum is still in process.

To monitor the evaluation efforts, the achievement criteria must be determined through questionnaires and check lists of the monitoring program

36 Stufflebeam, D.L, \& Shinkfied, A.J., Systematic Evaluation (Boston: Kluwer Nijhof Publishing, 1985), p. 159 . such as level of student satisfaction towards PAI lecturers.

This questionnaire aims to obtain data directly from each lecturer implementing Tri Dharma of Higher Education, both in the learning process, conducting research and publishing scientific papers, community service activities and other activities to enrich their knowledge. This questionnaire focuses more on extracting direct information about the implementation of the learning process. Through questionnaires, lecturers' preparedness and lecture implementation as part of learning process can be easily obtained.

Whereas, check List was designed to verify the results of the data collection through the two questionnaires. Check list is to check the correctness of information from the questionnaire and to find out additional information.

\section{Conclusion}

This paper concludes that curriculum planning for PAI learning begins with lecturer needs analysis in accordance with the number of students and classes, lecturers or course distribution. In addition, several things need to be prepared when planning such as syllabus, semester program, and lesson Plan (RPP) or Lecture Program Unit (SAP). In addition to this, PAI lecturers were provide with authority to freely analyze the syllabus.

$$
\text { Organizing curriculum }
$$
development at PTU is an effort to establish cooperation between individuals or people in a group dealing with assigning duties, authorities, responsibilities, and their relationships in planning, directing, and controlling curriculum development. PAI curriculum development is required as it belongs to 
general courses. When using and selecting a method, a lecturer needs to pay attention to the learning objectives, the nature of the subject matter, the condition of students, educators' ability and time allocation.

Curriculum is the first thing should be implemented in daily academic activities as part of learning process. Various learning competencies become the important factors. For instance, lecturers' competencessuch as mastering the material, mastering learning strategies, and also skills in using and utilizing learning resources are some important factors to take the curriculum into practice. In universities, lecturers and students are the key factors to determine the achievement of learning objectives. Lecturers should master various learning abilities as well as learning strategies.

Monitoring and evaluating curriculum is a systematic effort to collect information of value and meaning of the curriculum in a particular context to be used in the implementation process. Monitoring is carried out through regular data collection to find out whether the ongoing activities are in accordance with the plans and procedures. Evaluation focuses more on the study of the program results. Periodic evaluation is a systematic process of collecting, analyzing, and interpreting data to determine the success of a program, as well as identify which program components work well.

Anshari,Zainal. "Pendidikan Agama Islam dan Realitasnya di Perguruan Tinggi Umum", Edu-Islamika The Indonesian Journal of Education and Islamic Sciencies, 2 Vol 4, September,2012.

Arikunto,Suharsimi.

PengelolaanKelasdanSiswa:SebuahPendek
atanEvaluatif. Jakarta:CV. Rajawali, 1986.

Daulay, Haidar Putra, Pemberdayaan Pendidikan Islam di In donesia.

Dokumen. Modul Acuan Proses Pembelajaran Mata kuliah Pengembangan Kepribadian(PAI) UPT.BSMKU Universitas Jember.

Fatah, Nanang. Landasan Manajemen Pendidikan. Rosdakarya: Bandung,2001.

---------. Landasan Manajemen Pendidikan, Bandung: Remaja Rosdakarya. 1999.

Gunawan, Heri. Kurikulum dan Pembelajaran Pendididikan Agama Islam, Bandung: Alfabeta. 2013.

Hadiyanto, Andi.Standar Nasional Pendidikan Agama Islam Pada perguruan TinggiUmum, (Direktorat Pendidikan Tinggi Islam. Direktorat Jenderal pendidikan Islam KementerianAgama RI , Jakarta. 2010.

Hamalik, Oemar. Pengembangan Kurikulum dan Pembelajaran; Dasar dan Strategi Pelaksanaannya di Perguruan Tinggi. Bandung: Trigenda Karya, 1994.

J. Schereens. Menjadikan Sekolah Efektif. Jakarta: Logos, 2003.

Kasman. "Faktor-Faktor yang Mempengaruhi Motivasi Mahasiswa dalam Mengikuti Perkuliahan Pendidikan Agama Islam pada Perguruan Tinggi Umum di Kabupaten Jember Tahun 2005,". Fenomena, Jurnal Penelitian STAIN Jember, 2 Vol.5. Juli, 2006.

Kementerian Pedidikan dan Kebudayaan RI. Modul Pelatihan PengembanganSistem Monitoring dan Evaluasi ProgramProgram Pendidikan. 2013

Muhaimin, dkk, Pengembangan Model Kurikulum Tingkat Satuan Pendidikan (KTSP)pada Sekolah \& Madrasah.

--_-----. Pengembangan Pendidikan Ulul Albab di UIN Malang dalam M.Zainuddin dkk. Memadu Sains dan Agama Menuju Universitas Islam Masa Depan. UIN Malang Press: Malang, 2004.PT.Rineka Cipta: Jakarta. 2009. 
Richard L, Daft.Manajemen, Terj. Emil Salim, dkk. Jakarta: Erlangga, 2002.

Sanjaya, Wina. Strategi Pembelajaran Berorientasi Standar Proses Pendidikan Jakarta: Kencana, 2006.

Standar Nasional Pendidikan PP.No. 19 Tahun 2005.Pasal 9. yang dirubah menjadi PPNo.32 Tahun 2013. Bandung: Fokusmedia

Surachmi, Sri. "Pengembangan Profesi Pendidik dan Tenaga Kependidikan di Sekolah", Jurnal Ilmu Pengetahuan Sosial, 4Volume X. Oktober, 2008.

Syaiful. Administrasi Pendidikan Kontemporer. Bandung: Alfabeta, 2000.

Terry G.R., Principles of Management (3rd ed.). Homewood IL: Richard D. Irwin,INC, 1997.
Tim Dosen Administrasi Universitas Pendidikan Indonesia. Manajemen Pendidikan, Alfabeta: Bandung, 2009.

Undang-Undang Pendidikan Tinggi No.12 Tahun 2012. Jakarta. Sinar Grafika.

Undang-Undang RI Nomor: 20 Tahun 2003 tentang SISDIKNAS.

Usman,Husaini.Manajemen; Teori, Praktik dan Riset Pendidikan. Jakarta: Bumi Aksara,2010.

Uwes, Sanusi.Manajemen Pengembangan Mutu Dosen. Jakarta: Logos Wacana Ilmu. 1999.

Winoto, Suhadi.Manajemen Berbasis Sekolah, Jember: Pena Salsabila. 2011. 